\title{
Protective effects of sodium butyrate on rotavirus inducing endoplasmic reticulum stress-mediated apoptosis via PERK-elF2a signaling pathway in IPEC-J2 cells
}

Ye Zhao ${ }^{1 *+}$, Ningming Hu ${ }^{2,3+}$, Qin Jiang ${ }^{1 \dagger}$, Li Zhu ${ }^{1 *}$, Ming Zhang ${ }^{1}$, Jun Jiang ${ }^{1}$, Manyi Xiong ${ }^{1}$, Mingxian Yang ${ }^{1}$, Jiandong Yang ${ }^{1}$, Linyuan Shen ${ }^{1}$, Shunhua Zhang ${ }^{1}$, Lili Niu', Lei Chen ${ }^{1}$ and Daiwen Chen ${ }^{2,3^{*}}$

\begin{abstract}
Background: Rotavirus (RV) is a major pathogen that causes severe gastroenteritis in infants and young animals. Endoplasmic reticulum (ER) stress and subsequent apoptosis play pivotal role in virus infection. However, the protective mechanisms of intestinal damage caused by RV are poorly defined, especially the molecular pathways related to enterocytes apoptosis. Thus, the aim of this study was to investigate the protective effect and mechanism of sodium butyrate (SB) on RV-induced apoptosis of IPEC-J2 cells.

Results: The RV infection led to significant cell apoptosis, increased the expression levels of ER stress (ERS) markers, phosphorylated protein kinase-like ER kinase (PERK), eukaryotic initiation factor 2 alpha (elF2a), caspase9, and caspase3. Blocking PERK pathway using specific inhibitor GSK subsequently reversed RV-induced cell apoptosis. The SB treatment significantly inhibited RV-induced ERS by decreasing the expression of glucose regulated protein 78 (GRP78), PERK, and elF2a. In addition, SB treatment restrained the ERS-mediated apoptotic pathway, as indicated by downregulation of C/EBP homologous protein (CHOP) mRNA level, as well as decreased cleaved caspase9 and caspase3 protein levels. Furthermore, siRNA-induced GPR109a knockdown significantly suppressed the protective effect of SB on RV-induced cell apoptosis.

Conclusions: These results indicate that SB exerts protective effects against RV-induced cell apoptosis through inhibiting ERS mediated apoptosis by regulating PERK-elF2a signaling pathway via GPR109a, which provide new ideas for the prevention and control of RV.
\end{abstract}

Keywords: Apoptosis, IPEC-J2, PERK-eIF2a, Rotavirus, Sodium butyrate

\footnotetext{
*Correspondence: zhye3@foxmail.com; zhuli7508@163.com;

dwchen@sicau.edu.cn

${ }^{\dagger}$ Ye Zhao, Ningming Hu and Qin Jiang contributed equally to this work.

${ }^{1}$ College of Animal Science and Technology, Sichuan Agricultural University, Huimin Road 211\#, Chengdu, Sichuan Province 611130, P. R. China

${ }^{2}$ Institute of Animal Nutrition, Sichuan Agricultural University, Huimin Road

211\#, Chengdu, Sichuan Province 611130, P. R. China

Full list of author information is available at the end of the article
}

(c) The Author(s). 2021 Open Access This article is licensed under a Creative Commons Attribution 4.0 International License, which permits use, sharing, adaptation, distribution and reproduction in any medium or format, as long as you give appropriate credit to the original author(s) and the source, provide a link to the Creative Commons licence, and indicate if changes were made. The images or other third party material in this article are included in the article's Creative Commons licence, unless indicated otherwise in a credit line to the material. If material is not included in the article's Creative Commons licence and your intended use is not permitted by statutory regulation or exceeds the permitted use, you will need to obtain permission directly from the copyright holder. To view a copy of this licence, visit http://creativecommons.org/licenses/by/4.0/ The Creative Commons Public Domain Dedication waiver (http://creativecommons.org/publicdomain/zero/1.0/) applies to the data made available in this article, unless otherwise stated in a credit line to the data. 


\section{Introduction}

Rotavirus (RV) is the main cause of viral gastroenteritis in infants, young children, and young animals around the globe [1-3], which RV infection results in 12,000 to 15,000 annual deaths among children under 5 years each year [4, 5]. In addition, RV is responsible for $7 \%-50 \%$ mortality in piglets, causing great economic losses to the pork industry [6,7]. The RV is transmitted via the faecal-oral route. The faeces from an infected host contain more than 10 trillion pfu/gr of viruses, but less than 100 of them can transmit infection and make someone else sick [8]. The RV primary infects mature enterocytes and results in blunting, atrophy and fusion of villi, denudation of tip of villi and cryptal cells hyperplasia, thereby disrupting their physiological and absorptive function, which lead to diarrhoea $[9,10]$. Epidemiological researches have confirmed that RV in environment could contribute to the development of infectious gastrointestinal illness, which raising serious concerns about impacts on public health $[11,12]$. The detrimental effects of RV on public health have prompted substantial concern about how to efficiently protect the human or animal against RV infection.

Cell perception of various extracellular stimuli, such as viral infection, triggers specific intracellular signaling networks that results in cell apoptosis [13-15]. The RV infection causes intestinal barrier dysfunction and disrupts intestinal homeostasis, which could induce the apoptosis of epithelial cells $[9,16]$. Endoplasmic reticulum (ER) is a vital organelle that performs a variety of intracellular processes, including synthesis, folding, and post-translational modifications of proteins, and apoptosis, whose homeostasis is crucial for epithelial cells [17, 18]. Emerging reports have confirmed that virus infection could impair ER homeostasis in host cells and eventually lead to ER stress (ERS) $[17,19]$. The protein kinase RNA-like ER kinase (PERK) is one of the major ER transmembrane protein that is phosphorylated upon ERS. Subsequently, activation of PERK lead to the phosphorylation of $\alpha$-subunit of eukaryotic initiation factor 2 alpha $(e I F 2 \alpha)$ [20]. Phosphorylated $e I F 2 \alpha$ promotes the induction of activating transcription factor 4 (ATF4), which induces the expression of pro-apoptotic C/EBP homologous protein $(\mathrm{CHOP})$ [21]. The CHOP promoted apoptosis by increasing expression of the pro-apoptotic factor Bax and suppressing the expression of the antiapoptotic Bcl-2 [22, 23]. So far, numerous viruses have been demonstrated to induce cell apoptosis via PERKeIF $2 \alpha-C H O P$ signaling pathway in infected cells $[24,25]$. Kaposi's sarcoma-associated herpesvirus induces ERS,

Table 1 Primer sequences and optimal annealing temperatures (OAT) of genes selected for real-time PCR

\begin{tabular}{|c|c|c|c|}
\hline Name & Sequence $\left(5^{\prime} \rightarrow 3^{\prime}\right)$ & $\mathrm{OAT},{ }^{\circ} \mathrm{C}$ & GenBank ID \\
\hline$R V-Q F$ & TCAGTTCGTCAGGAATATGC & 53.5 & AF317123 \\
\hline$R V-\mathrm{QR}$ & CTTGAAGGTGAGTAGTTGGT & & \\
\hline GPR109a-QF & ATGCTGGACCCTTTGGTGTAT & 56.4 & XM021072989 \\
\hline GPR109a-QR & GGCTTGTGCTGCGGTTATT & & \\
\hline GRP78-QF & TCGGCGATGCAGCCAAGAAC & 59.8 & XM001927795 \\
\hline GRP78-QR & CGGGTCATTCCATGTCCGGC & & \\
\hline PERK-QF & CTGCCACTTCAGCATCATTC & 61.7 & XM021086085 \\
\hline PERK-QR & TTCCATCCAGGTCACCACAT & & \\
\hline IREI-QF & CGTCCTGGATCCAAAACT & 54 & XM005668695 \\
\hline IREI-QR & GTCAGATAGCGCAGGGTCTC & & \\
\hline ATF6-QF & CCGAAGAGAAGAGCCATCTG & 60.3 & XM021089515 \\
\hline ATF6-QR & TCCTTTGATTTGCAGGGTTC & & \\
\hline CHOP-QF & CACTCTTGACCCTGCCTCTC & 58.4 & NM001144845 \\
\hline CHOP-QR & GACTGGAATCAGGCGAGTGT & & \\
\hline BCl-2-QF & TGTGTGTGGAGAGCGTCAACC & 62.5 & XM021099593 \\
\hline$B C l-2-Q R$ & CAGAGACAGCCAGGAGAAATCAA & & \\
\hline Bax-QF & CCACCAGCTCTGAGCAGATCA & 61.3 & XM003127290 \\
\hline Bax-QR & GCCGCCACTCGGAAAAA & & \\
\hline Caspase9-QF & GTCTGCCCACACCTAGTGAC & 61.7 & XM003127618 \\
\hline Caspase9-QR & AGGGGTCCCAGCCTCATTAT & & \\
\hline Caspase3-QF & TGGCGTGTCAGAAAATACCAGT & 60.5 & NM214131 \\
\hline Caspase3-QR & GATCCGTCCTTTGAATTTCGCC & & \\
\hline$\beta$-actin-QR & TCTGGCACCACACCTTCT & 59.0 & U07786 \\
\hline$\beta$-actin-QF & TGATCTGGGTCATCTTCTCAC & & \\
\hline
\end{tabular}




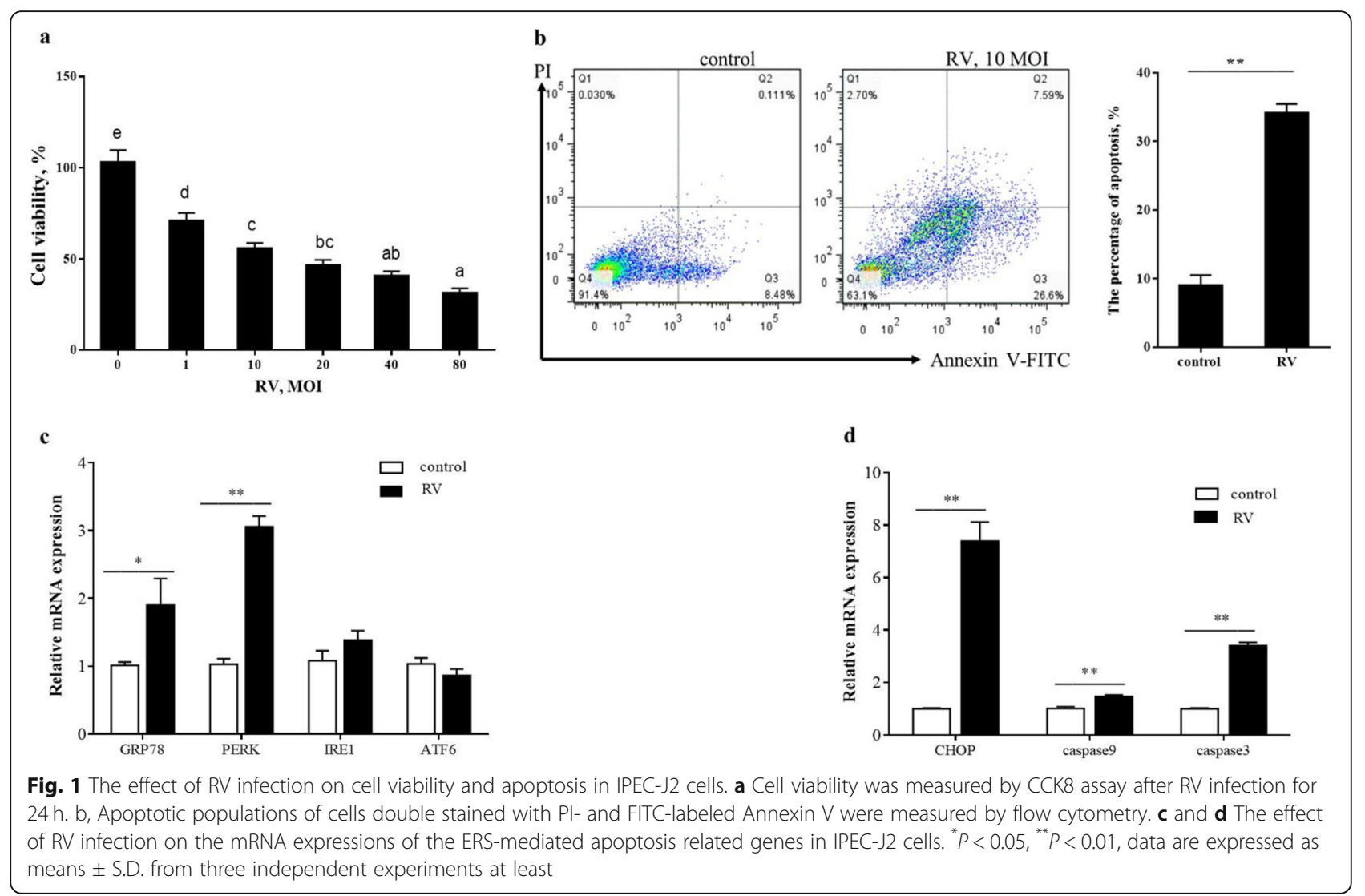

caspase activation, and $C H O P$ expression, which in turn results in apoptosis of primary effusion lymphoma cells [25]. Venezuelan equine encephalitis virus induced apoptosis through PERK-eIF2 $\alpha$-CHOP signaling pathway in infected U87MG cells [26]. Japanese encephalitis virus infection induced cell apoptosis by activating the PERKATF4-CHOP pathway in vitro and in vivo [27]. Nevertheless, whether RV could cause ERS-mediated cell apoptosis remains to be investigated.

Sodium butyrate (SB), a salt form of four-carbon shortchain fatty acid, has been endogenously produced by bacterial fermentation of dietary fibers in the colon [28]. Published studies have reported that SB has a wide range of pharmacological properties, including anti-inflammation, anti-oxidation, antitumor activities, and metabolism regulation [29-33]. The SB protects against lipopolysaccharide-induced endometritis through inhibiting inflammatory response in mice [34]. The latest study showed SB prevented tert-butyl hydroperoxide-induced oxidative stress and apoptosis in human nucleus pulposus cells [35]. The SB also could protect islet cells from apoptosis through inhibiting the PERK-CHOP pathway of ERS [36]. Despite, those results suggested that SB might play a critical role in reducing cell apoptosis. It is unknown whether SB could prevent RV-induced cell apoptosis. Therefore, based on the established RV infected intestinal epithelial cell model [37], we investigate for the first time the protective effect and mechanism of SB against $R V$-induced apoptosis via the PERK-eIF2 $\alpha$ signaling pathway in IPEC-J2 cells. These findings provide new ideas for prevention and control of RV.

\section{Materials and methods}

Cell culture and viral infection

The IPEC-J2 cell line (obtained from professor Per Torp Sangild, University of Copenhagen, Denmark) is isolated from the mid-jejunum epithelium of a neonatal unsuckled piglet. The IPEC-J2 cells were planted in DMEM/F12 medium supplemented with $10 \%$ fetal bovine serum, antibiotics (1\% penicillin-streptomycin), 5 $\mathrm{mg} / \mathrm{mL} \mathrm{hEGF}$, and $10 \mathrm{nmol} / \mathrm{L}$ HEPES, under an incubator of $5 \% \mathrm{CO}_{2}$ at $37^{\circ} \mathrm{C}$. The RV strain was purchased from China Institute of Veterinary Drug Control. Confluent (80\%) IPEC-J2 cells were infected with RV at multiplicity of infection (MOI) of 10 at $37^{\circ} \mathrm{C}$ for $1 \mathrm{~h}$. After that, the inoculum was carefully removed, and the cells were washed twice with PBS and cultured in fresh growth medium.

\section{PERK inhibitor treatments}

The cells were pre-treated with the PERK inhibitor GSK $(1.0 \mu \mathrm{mol} / \mathrm{L}$ and $10 \mu \mathrm{mol} / \mathrm{L})$ for $24 \mathrm{~h}$, followed by 


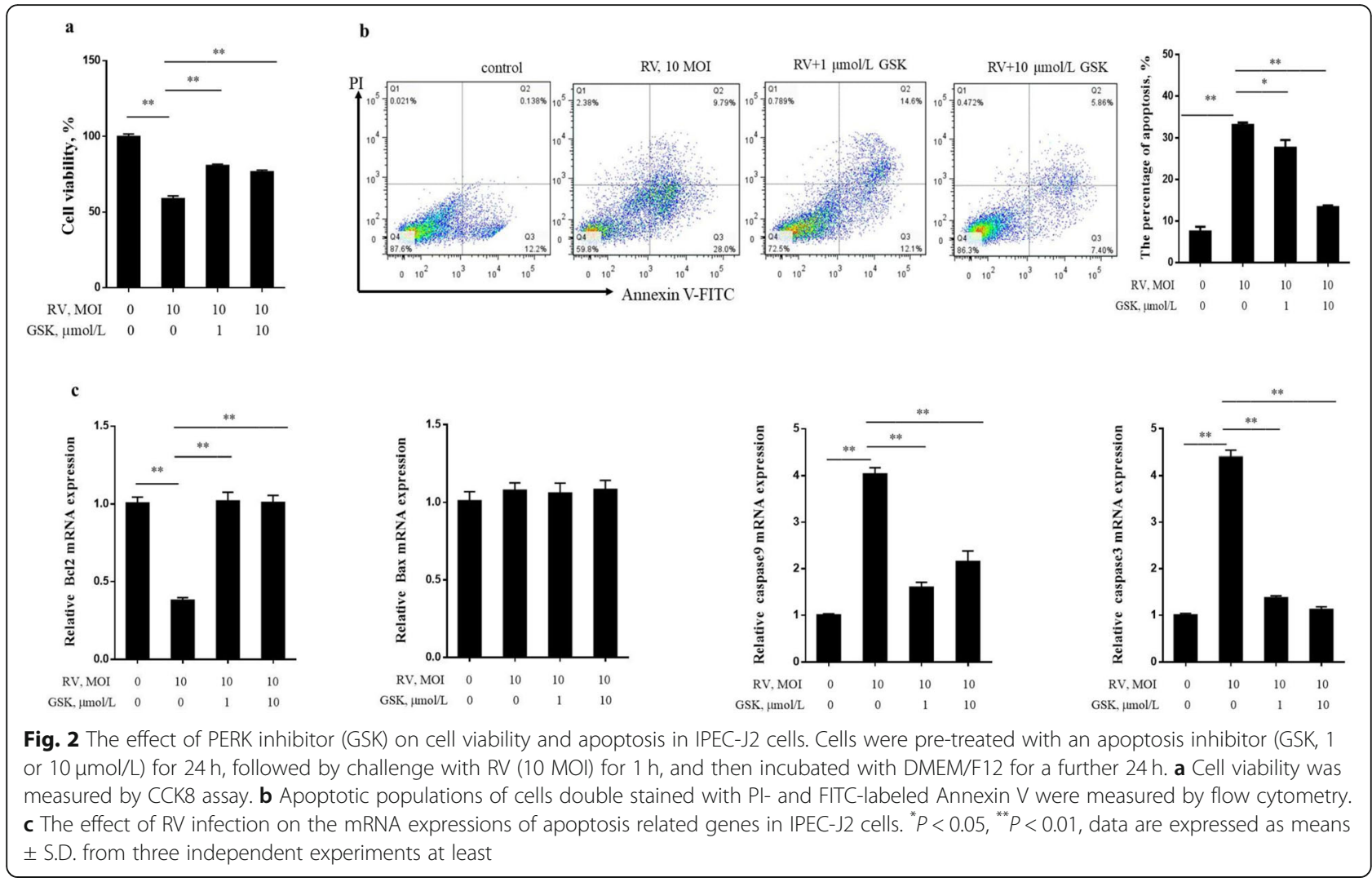

challenge with RV (10 MOI) for $1 \mathrm{~h}$, and then cultured with DMEM/F12 for a further $24 \mathrm{~h}$.

\section{SB treatments}

The SB (Sigma Aldrich, St. Louis, MO, USA) was dissolved in DMEM/F12 medium. Experimental procedures were based on the methods in our laboratory [37]. The concentration of SB was selected based on previous studies [38, 39]. Briefly, cells were cultured with different concentrations of $\mathrm{SB}(0,1,2,4,8$, and $16 \mathrm{mmol} / \mathrm{L})$ at $37^{\circ} \mathrm{C}$ with $5 \% \mathrm{CO}_{2}$ for $24 \mathrm{~h}$, followed by removing medium and washing with PBS three times, then challenged with RV at MOI of 10 for $1 \mathrm{~h}$. Next, removal of the inoculums and washing twice with PBS, the cells were incubated with basal medium (serum free) containing $\mathrm{SB}(0,1,2,4,8$, and $16 \mathrm{mmol} / \mathrm{L})$ for a further $24 \mathrm{~h}$.

\section{RNA interference}

GPR109a-specific siRNA1 (CGATGTTAATCAAGAA GCA), siRNA2 (GTAGCTTCAGCAT CTGCAA), and negative control siRNA (siCtrl) (RiboBio, Guangzhou, china) were used to knockdown GPR109a. The siGPR109a and siCtrl were transfected into IPEC-J2 using lipofectamine 3000 (Invitrogen, USA) following the manufacturer's procedures.

\section{Determination of cell viability and apoptosis}

The IPEC-I2 cells under different conditions seeded in sterile 96-well plates with cell density of $4 \times 10^{4} / \mathrm{mL}$ with $100 \mu \mathrm{L}$ medium. The Cell Counting Kit-8 (CCK-8) kit (Dojindo, Kumamoto, Japan) was adopted to measure the cell viability. Cell apoptosis was detected by Fluorescein isothiocynate (FITC)-, Alexa Fluor ${ }^{\circ} 647$ - conjugated Annexin $\mathrm{V}$ with propidium iodide (PI) staining assay (Biolegend) according to the manufacturer's protocols. Briefly, IPEC-J2 cells from the control and RV (GSK or $\mathrm{SB}$ or siRNA1) -treated groups were harvested and rinsed twice with PBS. Then, cells were resuspended in $100 \mu \mathrm{L} 1 \times$ binding buffer and incubated with Alexa Fluor 647 - conjugated Annexin V $\left(2 \mu \mathrm{L} / 10^{6}\right.$ cells) for 20 min on ice. Subsequently, $400 \mu \mathrm{L} 1 \times$ binding buffer and $1 \mu \mathrm{L}$ PI $(1 \mathrm{mg} / \mathrm{mL})$ were added successively and immediately analyzed by flow cytometry.

\section{Real-time quantitative PCR}

Total RNA was isolated from IPEC-J2 cells using RNAiso reagent (Invitrogen, Carlsbad, CA, USA) according to the manufacturer's instructions, followed by the synthesis of cDNA by the prime script ${ }^{\text {tix }} \mathrm{RT}$ reagent kit with gDNA eraser (Takara, Dalian, China). The RNA purity and integrity were assessed by spectrophotometric (A260 and $280 \mathrm{~nm}$ ratio) analysis and agarose gel (1\%) electrophoresis, respectively. Real-time quantitative PCR 


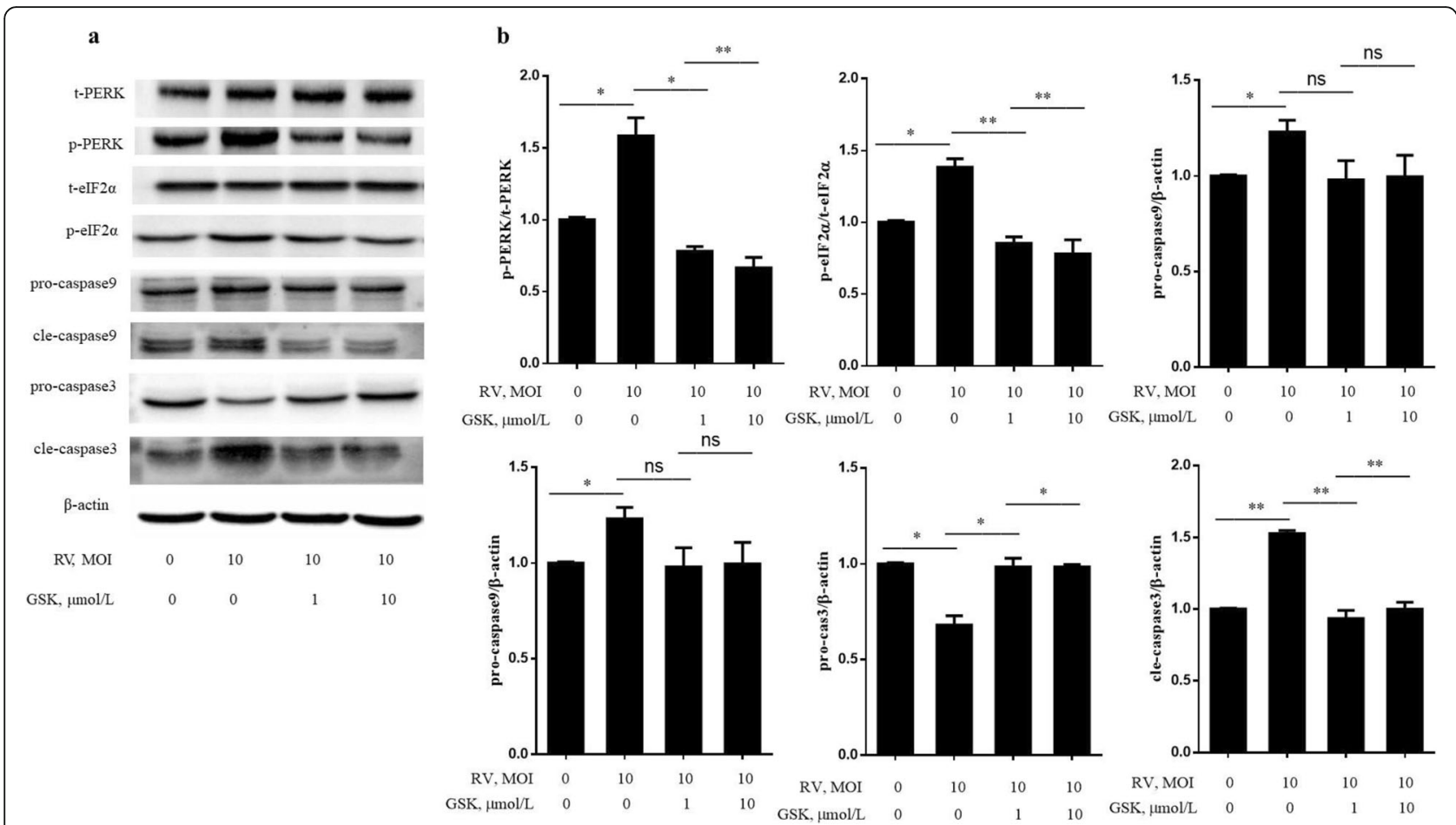

Fig. 3 The PERK inhibitor (GSK) alleviated RV induced apoptosis by regulating PERK-eIF2a signaling pathway in IPEC-J2 cells. Cells were pretreated with the PERK inhibitor (GSK, 1 or $10 \mu \mathrm{mol} / \mathrm{L}$ ) for $24 \mathrm{~h}$, followed by challenge with RV (10 MOI) for $1 \mathrm{~h}$, and then incubated with DMEM/ F12 for a further $24 \mathrm{~h}$. a The t-PERK, p-PERK, t-elF2a, p-elF2a, pro-caspase9, cle-caspase9, pro-caspase3, and cle-caspase3 protein levels were determined by western blot. $\mathbf{b}$ Results were expressed as the ratio of p-PERK and t-PERK, p-eIF2a and t-elF2a, pro-caspase9 and $\beta$-actin, clecaspase 9 and $\beta$-actin, pro-caspase 3 and $\beta$-actin, and cle-caspase 3 and $\beta$-actin protein levels. Equal loading was monitored with anti- $\beta$-actin antibody. ${ }^{*} P<0.05,{ }^{* *} P<0.01$, data are expressed as means \pm S.D. from three independent experiments at least

was carried out with a SYBR Premix EX Taq kit (TaKaRa, Dalian, China) and the CFX96 Real-Time PCR Detection System (Bio-Rad, Hercules, CA, USA). Relative gene expression was calculated with the $2^{-\Delta \Delta C T}$ method, normalizing the results to the value for the $\beta$ actin gene. Primer sequences used in this experiment are shown in Table 1.

\section{Western blotting}

Protein was isolated from cells using cold lysis buffer containing a proteinase and phosphatase inhibitor cocktail (Beyotime, Shanghai, China). The protein concentrations in the supernatants were measured using a BCA protein quantification kit (Beyotime, Shanghai, China). Samples containing equal amounts of protein $(20 \mu \mathrm{g})$ were separated by $10 \%$ SDS-polyacrylamide gel electrophoresis and then transferred to a polyvinyldifluoride membrane (BioRad Co. USA). The membranes were blocked and then incubated overnight at $4{ }^{\circ} \mathrm{C}$ with primary antibody (PERK, Santa Cruz Biotechnology, catalogue no.sc-377,400; phospho-PERK (p-PERK), Abcam, catalogue no. ab192591; eIF2 $\alpha$, Cell Signaling, catalogue no.5324; phospho-eIF $2 \alpha$ (p-eIF $2 \alpha$ ), Abcam, catalogue no. Ab32157; caspase9, Cell Signaling, catalogue no.9504; caspase3, Cell
Signaling, catalogue no. D3R6Y; $\beta$-actin, Cell Signaling, catalogue no. D6A8), washed four times using TBST (5 min each time). Then, the membrane was incubated with the corresponding HRP-conjugated secondary antibody at $25^{\circ} \mathrm{C}$ for $1 \mathrm{~h}$, washed four times with TBST for $20 \mathrm{~min}$, and visualized using ECL chemiluminescence kit (Beyotime, Shanghai, China). Finally, the Gel-Pro Analyzer was used to analyze protein densitometry. The relative expression levels of all protein were normalized to $\beta$-actin.

\section{Statistical analysis}

All results are expressed as means \pm SD. Data were analyzed using the statistical software SPSS 19.0 (SPSS Inc., Chicago, IL). All results were unpaired two-tailed Student's $\mathrm{T}$ test and/or one-way analysis of variance (ANOVA). $P<0.05$ and $P<0.01$ were statistically significant $\left(^{*}\right)$ and markedly significant $\left(^{* * *}\right)$ respectively.

\section{Results}

RV induces ERS mediated apoptosis in IPEC-J2 cells Initially, to define whether RV induce ERS mediated cell apoptosis, different assays were conducted in uninfectedand RV-infected IPEC-J2 cells at $24 \mathrm{~h}$ post-infection. As shown in the Fig. 1a and b, RV infection inhibited cell 


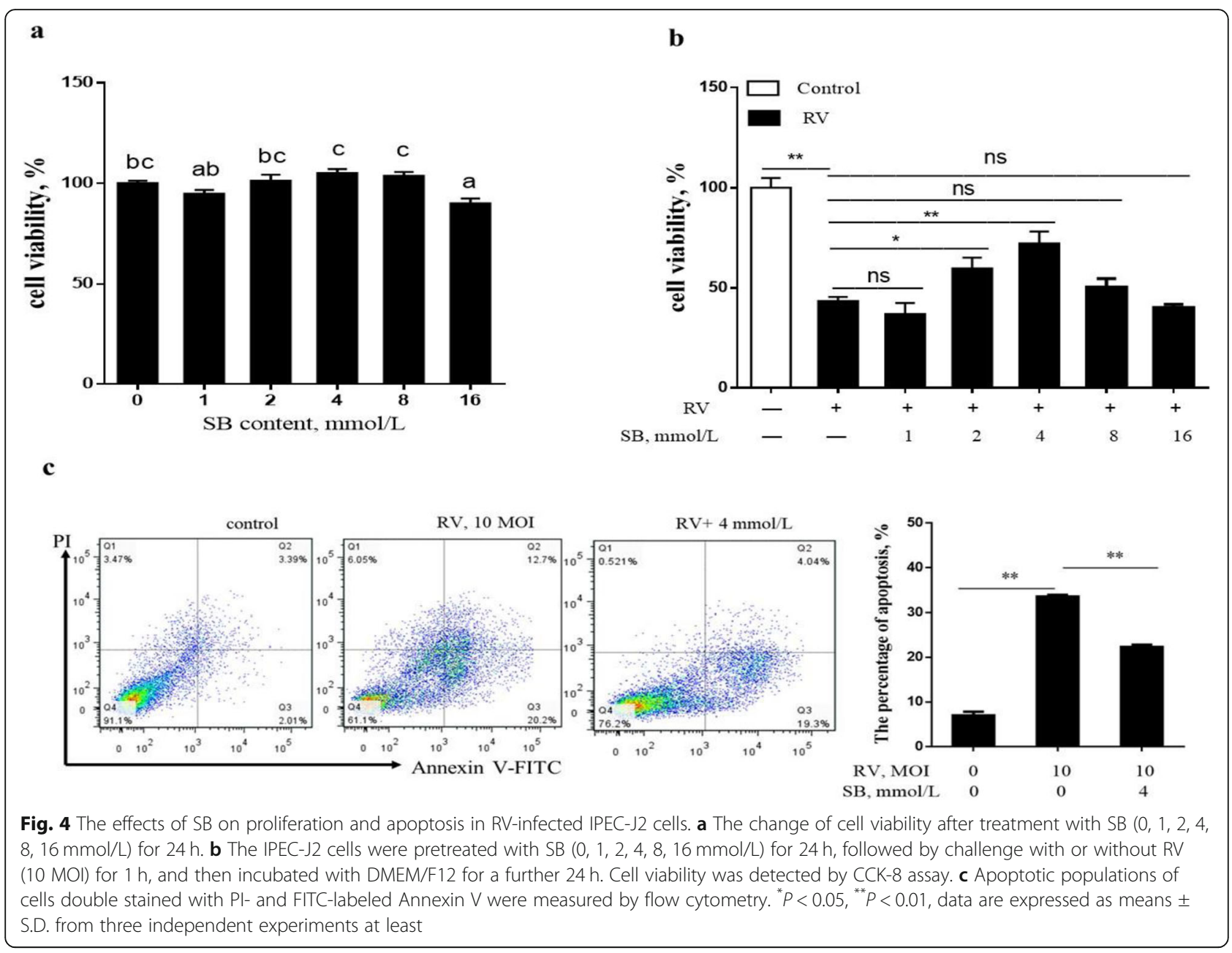

proliferation in a MOI-dependent mode. By using flow cytometry analysis, the percentage of apoptosis IPEC-J2 cells increased to $34.24 \%$ from a baseline of $9.08 \%$ after $\mathrm{RV}$ infection. In response to RV infection, an increase in the mRNA level of ERS marker GRP78 was observed (Fig. 1c). As shown in Fig. 1c and d, the mRNA levels of PERK, CHOP, caspase9, and caspase3 were significantly increased in $24 \mathrm{~h}$ post infected cells. Inhibition of PERK by GSK potently promoted the proliferation (Fig. 2a) and down-regulated caspase 9 and caspase 3 mRNA expression (Fig. 2c) of RV-infected IPEC-J2 cells. The apoptosis rate in RV infected cells pretreated with GSK $(10 \mu \mathrm{mol} / \mathrm{L})$ was significantly decreased compared to that in RV infected cells (Fig. 2b). Western blot analysis showed that p-PERK/t-PERK, p-eIF $2 \alpha / t$-eIF $2 \alpha$, and clecaspase 9 and cle-caspase 3 protein levels were significantly increased in $24 \mathrm{~h}$ post infected cells, while their protein levels were significantly decreased with PERK inhibitor treatment (Fig. 3a and b). These results collectively suggest that RV activates ERS and PERK-eIF2 $\alpha$ signaling pathway, which maybe an important reason of RV-induced cell apoptosis.

\section{SB ameliorates RV induced ERS mediated apoptosis in IPEC-J2 cells}

To determine whether SB could exert a protective effect against RV induced cell apoptosis. This study first examined the effect of SB $(0,1,2,4,8$, and $16 \mathrm{mmol} / \mathrm{L})$ on the IPEC-J2 cells viability. The SB had no cytotoxic effects up to the concentration of $8 \mathrm{mmol} / \mathrm{L}$ (Fig. $4 \mathrm{a}$ ) and tended (2 and $4 \mathrm{mmol} / \mathrm{L}$ ) to alleviate $\mathrm{RV}$ induced the decrease of the cell viability (Fig. 4b). Further the number of apoptotic cells after SB treatment was measured by using flow cytometry analysis. As expectedly, pretreatment of SB $(4 \mathrm{mmol} / \mathrm{L})$ significantly decreased the apoptosis in RV-infected IPECJ2 cells (Fig. 4c). As shown in Fig. 5a, b, e, f, and g, pretreated with SB ( 4 and $8 \mathrm{mmol} / \mathrm{L})$ cells showed a significant decrease in GRP78, PERK, CHOP, caspase9, and caspase3 mRNA expressions in RV infected IPEC-J2 cells. Together, these results suggested SB might ameliorate RV induced 


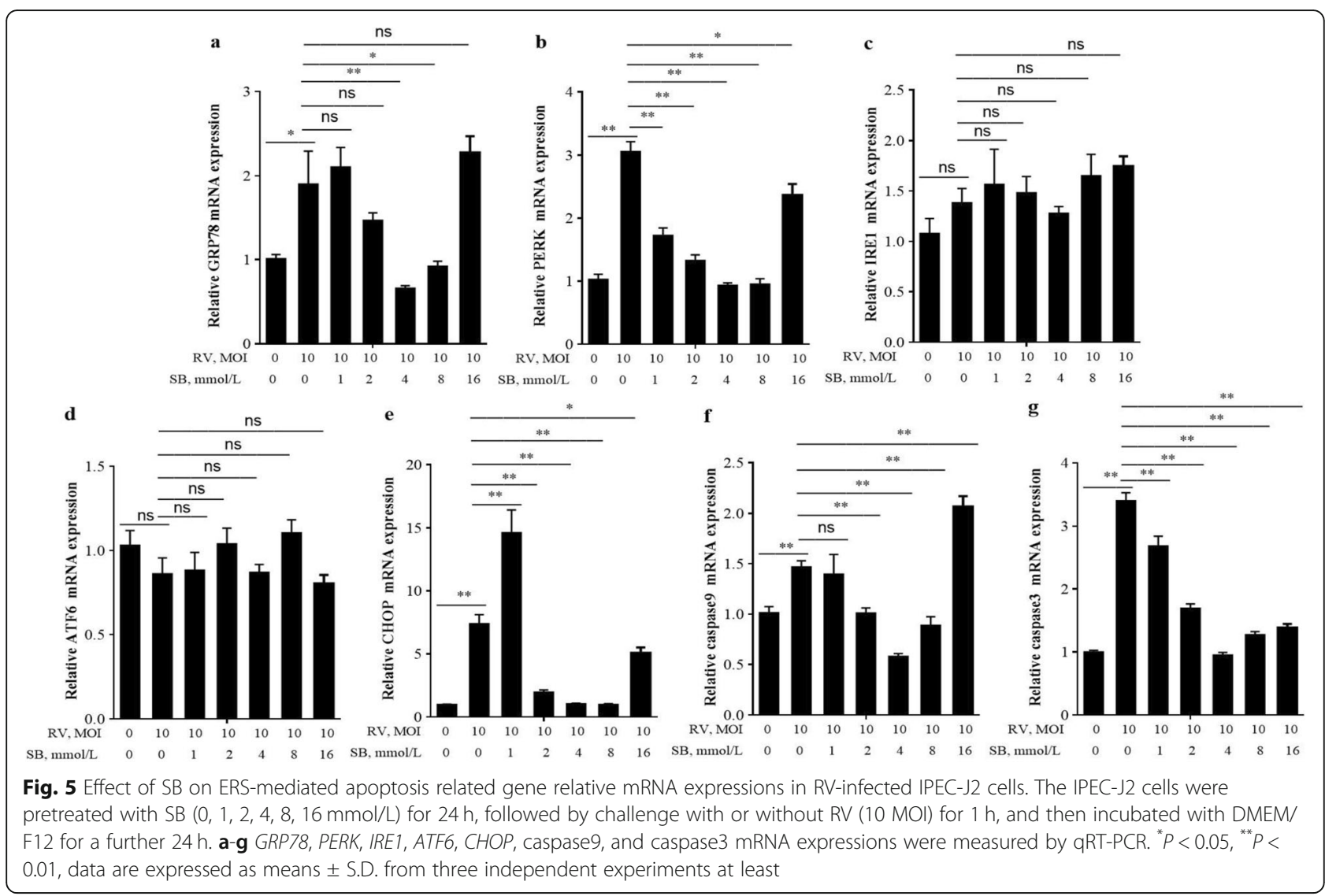

cell apoptosis via PERK-eIF2 $\alpha$ signaling pathway in IPEC-J2 cells.

\section{SB ameliorates RV induced cell apoptosis via GPR109a in IPEC-J2 cells}

To detect whether SB ameliorates RV induced cell apoptosis via GPR109a, this study first examined the effect of SB on GPR109a in RV infected IPEC-J2 cell. The SB (2, 4, and $8 \mathrm{mmol} / \mathrm{L}$ ) significantly up-regulated GPR109a mRNA expression (Fig. 6a). Then, two small interfering RNAs against GPR109a (GPR109a siRNA1 and GPR109a siRNA2) were transfected into IPEC-J2 cell. Compared with siRNA control, the expression of GPR109a were significantly down-regulated by GPR109a siRNAs (Fig. 6b), and transfection efficiency of siRNA1 was more significant than siRNA2 (data not shown). After SB treatment, the mRNA expression of GPR109a was significantly decreased by GPR109a siRNA1 in RV infected IPEC-J2 cell (Fig. 6c). Therefore, GPR109a siRNA1 was chose in the following experiments. Flow cytometry assays indicated GPR109a siRNA1 significantly increased apoptosis rate in RV infected IPEC-J2 cell (Fig. 6d). Besides, GPR109a siRNA1 remarkably suppressed the effect of $\mathrm{SB}$ on GRP78, PERK, eIF2 $\alpha$, ATF4, CHOP, Bcl2, caspase9, and caspase3 mRNA expressions in RV infected IPEC-J2 (Fig. 7). Western blot results showed that SB strongly decreased protein levels of
p-PERK, p-eIF2 $\alpha$, cle-caspase9, and cle-caspase3, but GPR109a siRNA1 attenuated this decrease in RV infected IPEC-J2 (Fig. 8a and b). In a word, these data revealed SB ameliorated RV induced cell apoptosis by regulating PERK-eIF2 $\alpha$ signaling pathway via GPR109a.

\section{Discussion}

As a major pathogenic factor, RV recently presents potential hazards to public health $[40,41]$. Enterocytes are the first block of defence against the entry of pathogens in the gut lumen. Because of the significant physiologic and morphologic similarities to enterocytes in vivo, IPEC-J2 cell line has been widely applied to characterize the interactions of enterocytes with RV in vitro [42]. The RV predominantly invades epithelial cells in the proximal intestine thereby causing villous atrophy and crypt hyperplasia. Then it is also accompanied by deadly watery diarrhea, resulting in severe dehydration and death in human and animals [9]. Accumulating evidences demonstrated that RV infection leaded to apoptosis of intestinal epithelial cells, which is an important reason for RV induced diarrhea in animals $[9,16]$. In this study, RV infection decreases viability of IPEC-J2 cells and increases the apoptosis rate. This result is consistent with a previous report in Caco-2 cells, which reported that RV infection leaded to the increase of DNA 


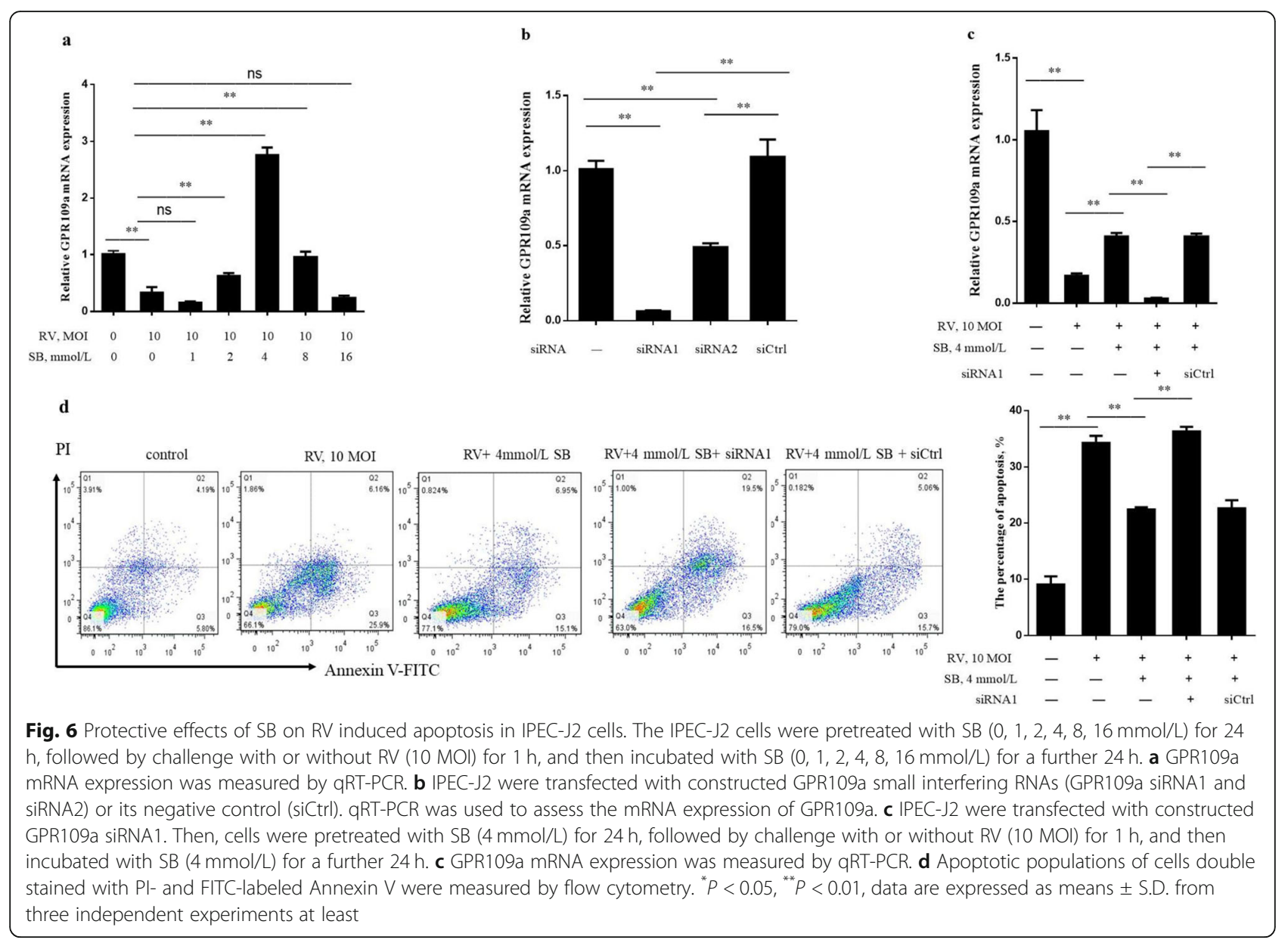

fragments and the loss of mitochondrial membrane potential [43]. Mao et al. also reported that RV infusion increased the apoptosis of the jejunal mucosal cells in piglet [16]. However, the present results indicated appropriate concentration of SB elevated the survival ratio and alleviated RV-induced cell apoptosis. These results indicate SB has an evident protective action against RVinduced IPEC-J2 cell apoptosis.

The PERK-eIF2 $\alpha$ pathway is an important signaling pathway that regulates ERS mediated apoptosis after virus infection $[26,27]$. The ER is the primary organelle for viral replication and maturation. Emerging evidences demonstrate that virus infection often disrupts the ER homeostasis and leads to activation of ERS [44-49]. The GRP78 and CHOP are contemporary and novel biomarkers of ERS [50]. In this study, mRNA expressions of GRP78 and CHOP were significantly increased in response to RV infection. These results suggested that RV infection might induce ERS. In normal, PERK, ATF6, and IRE1 are bound by GRP78. When ERS is activated, three transmembrane proteins separate from GRP78 that combines unfolded proteins. Subsequently, PERK and IRE 1 are activated by transautophorylation and ATF6 is activated by proteolytic processing [51]. This study also found that RV infection significantly increased phosphorylation of PERK but not IRE1 or ATF6. The PERK branch play a vital role in ERS related apoptosis. The activated PERK phosphorylates $e I F 2 \alpha$ on Ser51 site, inhibiting protein translation and synthesis. Subsequently, phosphorylated $e I F 2 \alpha$ selectively initiates the translation of $A T F 4$, which is required in the apoptotic response to ERS [52]. In this study, p-PERK, p-eIF2 $\alpha$, cle-caspase9, and cle-caspase 3 protein levels were significantly increased in RV infection cell, and caused a significant increase in cell apoptosis. To further demonstrate the direct involvement of PERK in RV-induced IPEC-J2 cell apoptosis, GSK was applied to verify the role of RV in ERS as a typical selective inhibitor of the PERK pathway. In this study, inhibition of PERK by GSK effectively reduced the expression of p-PERK and p-eIF2 $\alpha$, and RVinduced cell apoptosis. These results strongly suggested that the PERK-eIF2 $\alpha$ pathway is critically involved in RV induced cell apoptosis.

The SB is a mineral form of short-chain fatty acid that plays essential roles in regulating cell apoptosis $[35,53$, 54]. The previous study indicated that SB attenuated 

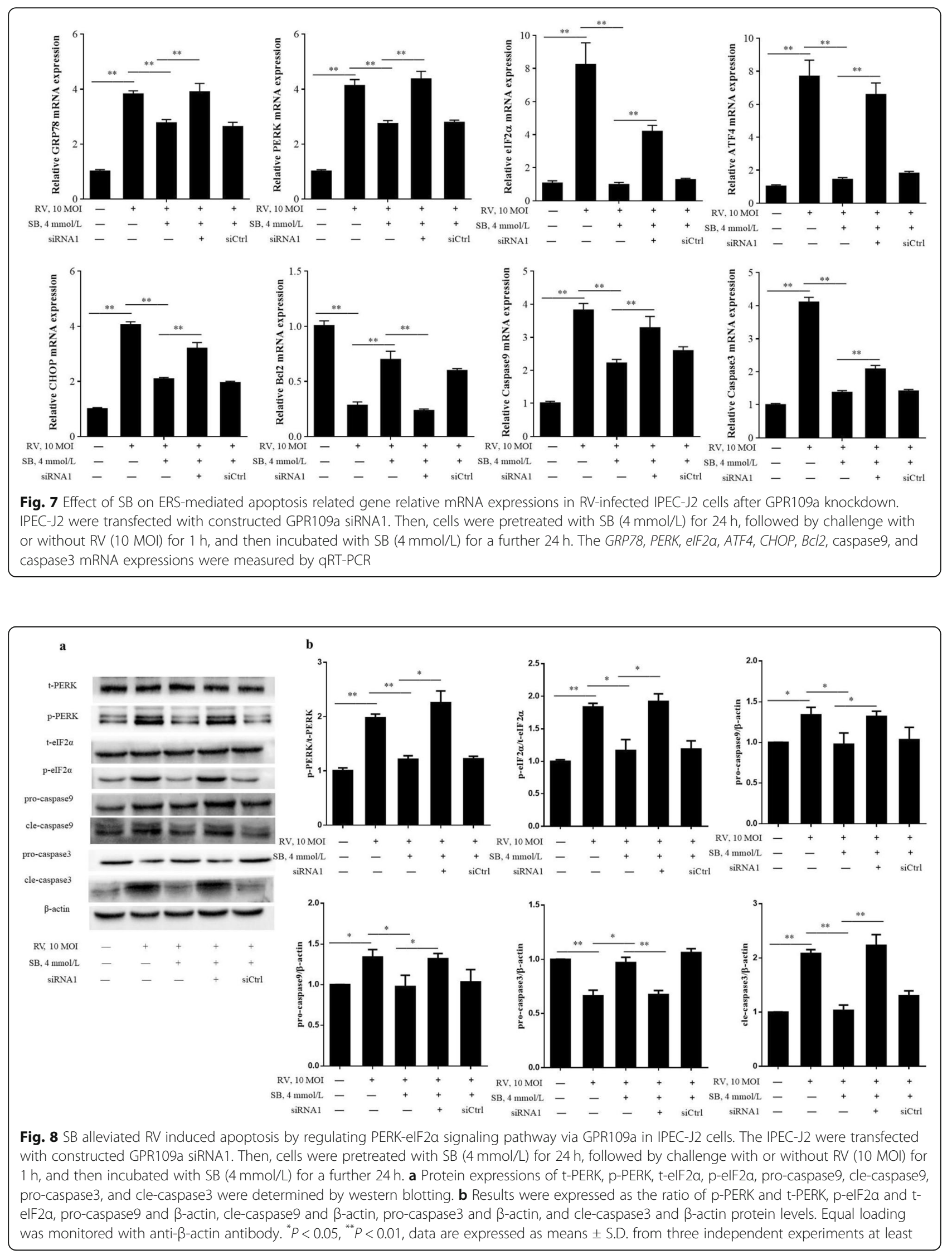
ERS induced islet $\beta$-cell apoptosis via inhibiting PERKeIF2 $\alpha$ signaling pathway in type 2 diabetic rats [36]. To further elucidate the potential mechanism of SB's protective effect on RV-induced cell apoptosis in IPEC-J2, this study examined the levels of ERS- and apoptosisrelated proteins. The present results showed protein levels of p-PERK, p-eIF2 $\alpha$, cle-caspase9, and clecaspase 3 were highly increased in response to RV infection. Moreover, pretreatment with SB effectively decreased p-PERK and p-eIF2 $\alpha$, cle-caspase9, and clecaspase3 protein levels. Collectively, these results indicated that SB ameliorated RV-induced apoptosis through PERK-eIF2 $\alpha$ signaling pathway. To our knowledge, this study is the first report demonstrating that SB protects IPEC-J2 against RV-induced apoptosis through inhibiting PERK-eIF2 $\alpha$ signaling pathway.

The GPR109a is a G protein-coupled receptor for butyrate and expresses in intestinal epithelium [55], which have been explored as mediators of the biological effects of short-chain fatty acids [56]. Butyrate has attracted more attention that it not only plays an important role in anti-inflammatory and immune regulation, but also participates in the protection against intestinal cancer in a GPR109a-dependent manner [32, 57-59]. The present study found SB increased GPR109a mRNA expression in IPEC-J2 cells. The siRNA-mediated gene silencing of GPR109a blunts the anti-apoptosis effect of SB and blocks SB-mediated suppression of PERK-eIF2 $\alpha$ signaling pathway, indicating that the protective role of $\mathrm{SB}$ might be related to the activation of GPR109a. This result was in good agreement with previous reports in piglet and mice. The SB ameliorates the 2, 4, 6trinitrobenzene sulfonic acid-induced inflammatory response and disruption of epithelial integrity through activating GPR109a [32] and exerted its anti-diarrheal effect on weaned piglets by up-regulating the expression of colon tight junction protein in a GPR109a-dependent manner [60]. Taken together, these data indicate SB alleviates $\mathrm{RV}$-induced apoptosis by regulating PERK-eIF2 $\alpha$ signaling pathway via GPR109a.

\section{Conclusions}

In conclusion, this study was the first to provide evidence that $\mathrm{SB}$ alleviated RV-induced apoptosis by regulating PERK-eIF2 $\alpha$ signaling pathway via GPR109a. These results highlighted a novel mechanism of SB in regulation of RV-induced apoptosis in intestinal epithelial cells.

\footnotetext{
Abbreviations

RV: Rotavirus; ER: Endoplasmic reticulum; SB: Sodium butyrate; ERS: Endoplasmic reticulum stress; PERK: Protein kinase-like ER kinase; elF2a: Eukaryotic initiation factor 2 alpha; GRP78: Glucose regulated protein 78; CHOP: C/EBP homologous protein; ATF4: Activating transcription factor 4; MOI: Multiplicity of infection; CCK8: Cell Counting Kit-8; FITC: Fluorescein isothiocynate; PI: Propidium iodide
}

\section{Acknowledgements}

The authors would like to express their sincere thanks to the personnel of these teams for their kind assistance.

\section{Authors' contributions}

Y. Z. and D. C. designed and provided guidance for the experiments. Y. Z., N. $H_{\text {., }}$ and Q. J. performed the experiments and wrote the manuscript. L. Z., M. Z., J. J., M. X., M. Y., and J. Y. performed the RT-PCR experiments and assisted in the manuscript preparation. L. S., S. Z., L. N., and L. C. analyzed and interpreted the data. All authors contributed to the experiments. The author(s) read and approved the final manuscript.

\section{Funding}

The study was supported by Key Program for the National Key Research \& Development Program of China (2018YFD0501004), the National Natural Science Foundation of China (31730091), and the Sichuan Science and Technology Support Program (2020YFN0147).

\section{Availability of data and materials}

The datasets produced and/or analyzed during the current study are available from the corresponding author on reasonable request.

\section{Declarations}

Ethics approval and consent to participate Not applicable.

\section{Consent for publication}

Not applicable.

\section{Competing interests}

The authors declare that they have no known competing financial interests or personal relationships that could have appeared to influence the work reported in this paper.

\section{Author details}

${ }^{1}$ College of Animal Science and Technology, Sichuan Agricultural University, Huimin Road 211\#, Chengdu, Sichuan Province 611130, P. R. China. ${ }^{2}$ Institute of Animal Nutrition, Sichuan Agricultural University, Huimin Road 211\#, Chengdu, Sichuan Province 611130, P. R. China. ${ }^{3}$ Key Laboratory for Animal Disease-Resistance Nutrition of China Ministry of Education, Sichuan Agricultural University, Chengdu, Sichuan 611130, P. R. China.

Received: 16 December 2020 Accepted: 6 April 2021

Published online: 11 June 2021

\section{References}

1. Hyser JM, Estes MK. Rotavirus vaccines and pathogenesis: 2008. Curr Opin Gastroenterol. 2009:25(1):36-43. https://doi.org/10.1097/MOG.0b013e32831 7c897.

2. Woode GN, Bridger JC, Jones JM, Flewett TH, Davies HA, Davis HA, et al. Morphological and antigenic relationships between viruses (rotaviruses) from acute gastroenteritis of children, calves, piglets, mice, and foals. Infect Immun. 1976;14(3):804-10. https://doi.org/10.1128/IAI.14.3.804-810.1976.

3. Mulyani NS, Prasetyo D, Karyana IPG, Sukardi W, Damayanti W, Anggraini D, et al. Diarrhea among hospitalized children under five: a call for inclusion of rotavirus vaccine to the national immunization program in Indonesia. Vaccine. 2018;36(51):7826-31. https://doi.org/10.1016/j.vaccine.2018.05.031.

4. Wang H, Naghavi M, Allen C, Barber RM, Bhutta ZA, Carter A, et al. Global, regional, and national life expectancy, all-cause mortality, and cause-specific mortality for 249 causes of death, 1980-2015: a systematic analysis for the global burden of disease study 2015. Lancet. 2016;388(10053):1459-544. https://doi.org/10.1016/S0140-6736(16)31012-1.

5. Wang P, Goggins WB, Chan EYY. A time-series study of the association of rainfall, relative humidity and ambient temperature with hospitalizations for rotavirus and norovirus infection among children in Hong Kong. Sci Total Environ. 2018;643:414-22. https://doi.org/10.1016/j.scitotenv.2018.06.189.

6. Guo Y, Candelero-Rueda RA, Saif LJ, Vlasova AN. Infection of porcine small intestinal enteroids with human and pig rotavirus A strains reveals contrasting roles for histo-blood group antigens and terminal sialic acids. 
PLoS Pathog. 2021;17(1):e1009237. https://doi.org/10.1371/journal.ppat.1 009237.

7. Saif $L$. Comparative pathogenesis of enteric viral infections of swine. Adv Exp Med Biol. 1999;473:47-59. https://doi.org/10.1007/978-1-4615-4143-1_4.

8. Asma S, Nazish B, Claude YK, Saadia N, Sadia S. Rotavirus: genetics, pathogenesis and vaccine advances. Rev Med Virol. 2018;28(6):e2003.

9. Mao X, Hu H, Xiao X, Chen D, Yu B, He J, et al. Lentinan administration relieves gut barrier dysfunction induced by rotavirus in a weaned piglet model. Food Funct. 2019;10(4):2094-101. https://doi.org/10.1039/C8FO01764F.

10. Snodgrass DR, Ferguson A, Allan F, Angus KW, Mitchell B. Small intestinal morphology and epithelial cell kinetics in lamb rotavirus infections. Gastroenterology. 1979;76(3):477-81. https://doi.org/10.1016/S00165085(79)80213-9.

11. Shamsollahi HR, Ghoochani M, Sadeghi K, Jaafari J, Masinaei M, Sillanpää M, et al. Evaluation of the physical and chemical characteristics of water on the removal efficiency of rotavirus in drinking water treatment plants and change in induced health risk. Process Saf Environ Prot. 2019;130:6-13. https://doi.org/10.1016/j.psep.2019.07.014.

12. Prez VE, Gil Pl, Temprana CF, Cuadrado PR, Martínez LC, Giordano MO, et al. Quantification of human infection risk caused by rotavirus in surface waters from Córdoba, Argentina. Sci Total Environ. 2015;538:220-9. https://doi.org/1 0.1016/j.scitotenv.2015.08.041

13. Shen $X$, Yin $L$, Pan $X$, Zhao R, Zhang D. Porcine epidemic diarrhea virus infection blocks cell cycle and induces apoptosis in pig intestinal epithelial cells. Microb Pathog. 2020;147:104378. https://doi.org/10.1016/j.micpath.202 0.104378 .

14. Mitomo S, Omatsu T, Tsuchiaka S, Nagai M, Furuya T, Mizutani T. Activation of c-Jun N-terminal kinase by akabane virus is required for apoptosis. Res Vet Sci. 2016;107:147-51. https://doi.org/10.1016/j.rvsc.2016.06.007.

15. Huang $X$, Liu W, Zhang J, Liu Z, Wang M, Wang L, et al. Very virulent infectious bursal disease virus-induced immune injury is involved in inflammation, apoptosis, and inflammatory cytokines imbalance in the bursa of fabricius. Dev Comp Immunol. 2021;114:103839. https://doi.org/10.1016/j. dci.2020.103839

16. Mao X, Gu C, Hu H, Tang J, Chen D, Yu B, et al. Dietary lactobacillus rhamnosus $\mathrm{GG}$ supplementation improves the mucosal barrier function in the intestine of weaned piglets challenged by porcine rotavirus. PLoS One. 2016;11(1):e0146312. https://doi.org/10.1371/journal.pone.0146312.

17. Zhang $Q, X u Y$, Chang $R$, Tong $D, X u X$. Transmissible gastroenteritis virus $N$ protein causes endoplasmic reticulum stress, up-regulates interleukin-8 expression and its subcellular localization in the porcine intestinal epithelial cell. Res Vet Sci. 2018;119:109-15. https://doi.org/10.1016/j.rvsc.2018.06.008.

18. Wu X, Sun L, Zha W, Studer E, Gurley E, Chen L, et al. HIV protease inhibitors induce endoplasmic reticulum stress and disrupt barrier integrity in intestinal epithelial cells. Gastroenterology. 2010;138(1):197-209. https://doi. org/10.1053/j.gastro.2009.08.054.

19. Turpin J, Frumence E, Harrabi W, Haddad JG, El Kalamouni C, Desprès $P$, et al. Zika virus subversion of chaperone GRP78/BiP expression in A549 cells during URP activation. Biochimie. 2020;175:99-105. https://doi.org/10.1016/j. biochi.2020.05.011.

20. Malhotra JD, Kaufman RJ. The endoplasmic reticulum and the unfolded protein response. Semin Cell Dev Biol. 2007;18(6):716-31. https://doi.org/1 0.1016/j.semcdb.2007.09.003

21. Gu Y, Wang Y, Bai Y, Liu M, Wang H. Endoplasmic reticulum stress and apoptosis via PERK-elF2a-CHOP signaling in the methamphetamine-induced chronic pulmonary injury. Environ Toxicol Pharmacol. 2017;49:194-201. https://doi.org/10.1016/..etap.2017.01.003.

22. Aw TY. GADD153 sensitized cells to ER stress by down-regulating $B c 12$ and perturbing the cellular redox state. Mol Cell Biol. 2001:21(4):1249-59.

23. Puthalakath $H$, O'Reilly LA, Gunn P, Lee L, Kelly PN, Huntington ND, et al. ER stress triggers apoptosis by activating BH3-only protein Bim. Cell. 2007; 129(7):1337-49. https://doi.org/10.1016/j.cell.2007.04.027.

24. Catanzaro N, Meng X. Induction of the unfolded protein response (UPR) suppresses porcine reproductive and respiratory syndrome virus (PRRSV) replication. Virus Res. 2020;276:197820. https://doi.org/10.1016/j.virusres.2019.197820.

25. Shigemi Z, Baba Y, Hara N, Matsuhiro J, Kagawa H, Watanabe T, et al. Effects of ER stress on unfolded protein responses, cell survival, and viral replication in primary effusion lymphoma. Biochem Biophys Res Commun. 2016:469(3): 565-72. https://doi.org/10.1016/j.bbrc.2015.12.032.

26. Baer A, Lundberg L, Swales D, Waybright N, Pinkham C, Dinman JD, et al. Venezuelan equine encephalitis virus induces apoptosis through the unfolded protein response activation of EGR1. J Virol. 2016;90(7):3558-72. https://doi.org/10.1128/JVI.02827-15.

27. Wang $Q$, Xin $X$, Wang $T$, Wan J, Ou Y, Yang Z, et al. Japanese encephalitis virus induces apoptosis and encephalitis by activating the PERK pathway. Virol. 2019;93(17):e00887-19.

28. Guilloteau P, Martin L, Eeckhaut V, Ducatelle R, Zabielski R, Van Immerseel F. From the gut to the peripheral tissues: the multiple effects of butyrate. Nutr Res Rev. 2010;23(2):366-84. https://doi.org/10.1017/S0954422410000247.

29. Huang W, Zeng C, Liu J, Yuan L, Liu W, Wang L, et al. Sodium butyrate induces autophagic apoptosis of nasopharyngeal carcinoma cells by inhibiting AKT/mTOR signaling. Biochem Biophys Res Commun. 2019;514(1): 64-70. https://doi.org/10.1016/j.bbrc.2019.04.111.

30. Pant K, Yadav AK, Gupta P, Islam R, Saraya A, Venugopal SK. Butyrate induces ROS-mediated apoptosis by modulating miR-22/SIRT-1 pathway in hepatic cancer cells. Redox Biol. 2017;12:340-9. https://doi.org/10.1016/j. redox.2017.03.006

31. Gálfi P, Neogrády S, Kutas F, Veresegyházy T. Influence of sodium butyrate on hela cell morphology and proliferation. Life Sci. 1985;37(24):2257-68. https://doi.org/10.1016/0024-3205(85)90016-5.

32. Chen G, Ran X, Li B, Li Y, Wang W. Sodium butyrate inhibits inflammation and maintains epithelium barrier integrity in a TNBS-induced inflammatory bowel disease mice model. EBioMedicine. 2018;30:317-25. https://doi.org/1 0.1016/j.ebiom.2018.03.030.

33. Machado RA, Constantino LDS, Tomasi CD, Rojas HA, Vuolo FS, Vitto MF, et al. Sodium butyrate decreases the activation of NF-KB reducing inflammation and oxidative damage in the kidney of rats subjected to contrast-induced nephropathy. Nephrol Dial Transplant. 2012;27(8):3136-40. https://doi.org/10.1093/ndt/gfr807.

34. Guo J, Wang Y, Jiang P, Yao H, Zhao C, Hu X, et al. Sodium butyrate alleviates lipopolysaccharide-induced endometritis in mice through inhibiting inflammatory response. Microb Pathog. 2019;137:103792. https:// doi.org/10.1016/j.micpath.2019.103792.

35. Liu X, Jiang C, Liu G, Wang P, Shi M, Yang M, et al. Sodium butyrate protects against oxidative stress in human nucleus pulposus cells via elevating PPARY-regulated Klotho expression. Int Immunopharmacol. 2020; 85:106657. https://doi.org/10.1016/.jintimp.2020.106657.

36. Hu Y, Liu J, Yuan Y, Chen J, Cheng S, Wang H, et al. Sodium butyrate mitigates type 2 diabetes by inhibiting PERK-CHOP pathway of endoplasmic reticulum stress. Environ Toxicol Pharmacol. 2018;64:112-21. https://doi. org/10.1016/j.etap.2018.09.002.

37. Zhao Y, Ran Z, Jiang Q, Hu N, Yu B, Zhu L, et al. Vitamin D alleviates rotavirus infection through a microrna-155-5p mediated regulation of the TBK1/INF3 signaling pathway in vivo and in vitro. Int J Mol Sci. 2019;20(14): 3562. https://doi.org/10.3390/ijms20143562.

38. Qiao CM, Sun MF, Jia XB, Shi Y, Zhang BP, Zhou ZL, et al. Sodium butyrate causes alpha-synuclein degradation by an Atg5-dependent and PI3K/Akt/ mTOR-related autophagy pathway. Exp Cell Res. 2020;387(1):111772. https:// doi.org/10.1016/j.yexcr.2019.111772.

39. Sun X, Luo S, Jiang C, Tang Y, Cao Z, Jia H, et al. Sodium butyrate reduces bovine mammary epithelial cell inflammatory responses induced by exogenous lipopolysaccharide, by inactivating NF-KB signaling. J Dairy Sci. 2020;103(9):8388-97. https://doi.org/10.3168/jds.2020-18189.

40. Pang X, Qiu Y, Gao T, Zurawell R, Neumann NF, Craik S, et al. Prevalence, levels and seasonal variations of human enteric viruses in six major rivers in Alberta, Canada. Water Res. 2019;153:349-56. https://doi.org/10.1016/j.watres.2019.01.034.

41. Kadai AM, Bello HS, Ghamba PE, Dauda FA, Abdullahi IN. Environmental survey of rotavirus in sewage water within Maiduguri Metropolis, Nigeria. J Infect Dis. 2020;10(2):207-12

42. Liu F, Li G, Wen K, Bui T, Cao D, Zhang Y, et al. Porcine small intestinal epithelial cell line (IPEC-J2) of rotavirus infection as a new model for the study of innate immune responses to rotaviruses and probiotics. Viral Immunol. 2010;23(2):135-49. https://doi.org/10.1089/vim.2009.0088.

43. Cha Bi C, Cotte-Laffitte J, Sandré C, Esclatine A, Servin AL, Quéro AM, et al. Rotavirus induces apoptosis in fully differentiated human intestinal Caco-2 cells. Virology. 2005;332(2):480-90. https://doi.org/10.1016/j.virol.2004.11.039.

44. Ambrose RL, Mackenzie JM. West Nile virus differentially modulates the unfolded protein response to facilitate replication and immune evasion. J Virol. 2011;85(6):2723-32. https://doi.org/10.1128/JVI.02050-10.

45. Bechill J, Chen Z, Brewer JW, Baker SC. Coronavirus infection modulates the unfolded protein response and mediates sustained translational repression. J Virol. 2008;82(9):4492-501. https://doi.org/10.1128/JVI.00017-08. 
46. Cheng G, Feng Z, He B. Herpes simplex virus 1 infection activates the endoplasmic reticulum resident kinase perk and mediates elF-2a dephosphorylation by the $\gamma_{1} 34.5$ protein. J Virol. 2005;79(3):1379-88. https:// doi.org/10.1128/JVI.79.3.1379-1388.2005.

47. Isler JA, Skalet AH, Alwine JC. Human cytomegalovirus infection activates and regulates the unfolded protein response. J Virol. 2005;79(11):6890-9. https://doi.org/10.1128/JVI.79.11.6890-6899.2005.

48. Medigeshi GR, Lancaster AM, Hirsch AJ, Briese T, Lipkin WI, Defilippis V, et al. West Nile virus infection activates the unfolded protein response, leading to CHOP induction and apoptosis. J Virol. 2007:81(20):10849-60. https://doi. org/10.1128/JVI.01151-07.

49. Pavio N, Romano PR, Graczyk TM, Feinstone SM, Taylor DR. Protein synthesis and endoplasmic reticulum stress can be modulated by the hepatitis $C$ virus envelope protein E2 through the eukaryotic initiation factor 2a kinase PERK. J Virol. 2003;77(6):3578-85. https://doi.org/10.1128/JVI.77.6.3578-3585.2 003.

50. Kim I, Xu W, Reed JC. Cell death and endoplasmic reticulum stress: disease relevance and therapeutic opportunities. Nat Rev Drug Discov. 2008;7(12): 1013-30. https://doi.org/10.1038/nrd2755.

51. Zhang K, Kaufman RJ. Signaling the unfolded protein response from the endoplasmic reticulum. J Biol Chem. 2004;279(25):25935-8. https://doi.org/1 0.1074/jbc.R400008200

52. Tabas I, Ron D. Integrating the mechanisms of apoptosis induced by endoplasmic reticulum stress. Nat Cell Biol. 2011;13(3):184-90. https://doi. org/10.1038/ncb0311-184.

53. Sekhavat A, Sun JM, Davie JR. Competitive inhibition of histone deacetylase activity by trichostatin A and butyrate. Biochem Cell Biol. 2007;85(6):751-8. https://doi.org/10.1139/007-145.

54. Zhang L, Du J, Yano N, Wang H, Zhao YT, Dubielecka PM, et al. Sodium butyrate protects against high fat diet-induced cardiac dysfunction and metabolic disorders in type II diabetic mice. Cell Biochem. 2017;118(8):2395408. https://doi.org/10.1002/jcb.25902.

55. Ganapathy V, Thangaraju M, Prasad PD, Martin PM, Singh N. Transporters and receptors for short-chain fatty acids as the molecular link between colonic bacteria and the host. Curr Opin Pharmacol. 2013;13(6):869-74. https://doi.org/10.1016/j.coph.2013.08.006.

56. Blad CC, Tang C, Offermanns S. G protein-coupled receptors for energy metabolites as new therapeutic targets. Nat Rev Drug Discov. 2012;11(8): 603-19. https://doi.org/10.1038/nrd3777.

57. Elangovan S, Pathania R, Ramachandran S, Ananth S, Padia RN, Lan L, et al. The niacin/butyrate receptor GPR109A suppresses mammary tumorigenesis by inhibiting cell survival. Cancer Res. 2014;74(4):1166-78. https://doi.org/1 0.1158/0008-5472.CAN-13-1451.

58. Guo W, Liu J, Sun J, Gong Q, Ma H, Kan X, et al. Butyrate alleviates oxidative stress by regulating Nrf2 nuclear accumulation and $\mathrm{H} 3 \mathrm{~K} 9 / 14$ acetylation via GPR109A in bovine mammary epithelial cells and mammary glands. Free Radic Biol Med. 2020;152:728-42. https://doi.org/10.1016/j.freeradbiomed.2 020.01.016.

59. Singh N, Gurav A, Sivaprakasam S, Brady E, Padia R, Shi H, et al. Activation of GPR109a, receptor for niacin and the commensal metabolite butyrate, suppresses colonic inflammation and carcinogenesis. Immunity. 2014;40(1): 128-39. https://doi.org/10.1016/j.immuni.2013.12.007.

60. Feng W, Wu Y, Chen G, Fu S, Li B, Huang B, et al. Sodium butyrate attenuates diarrhea in weaned piglets and promotes tight junction protein pxpression in colon in a GPR109A-dependent manner. Cell Physiol Biochem. 2018:47(4):1617-29. https://doi.org/10.1159/000490981.

\section{Ready to submit your research? Choose BMC and benefit from:}

- fast, convenient online submission

- thorough peer review by experienced researchers in your field

- rapid publication on acceptance

- support for research data, including large and complex data types

- gold Open Access which fosters wider collaboration and increased citations

- maximum visibility for your research: over $100 \mathrm{M}$ website views per year

At BMC, research is always in progress.

Learn more biomedcentral.com/submissions 